\title{
ANALYSING RIVERBED MORPHOLOGY AS A RESPONSE TO CHANGES OF GEOLOGICAL AND NEOTECTONIC CONDITIONS: A CASE STUDY OF THE OL'ŠAVA RIVER
}

\author{
Dušan Barabas @ , MATúš TKÁČ @ \\ Institute of Geography, Pavol Jozef Šafárik University in Košice, Slovak Republik
}

Manuscript received: May 10, 2019

Revised version: August 12, 2019

BARABAS D., TKÁČ M., 2019. Analysing riverbed morphology as a response to changes of geological and neotectonic conditions: a case study of the Ol'šava river. Quaestiones Geographicae 38(3), Bogucki Wydawnictwo Naukowe, Poznań, pp. 109-122. 6 figs, 2 tables.

ABSTRACT: The morphological examination of the Slovak Ol'šava River channel and valley parameters is based on observation of changes in the troughs' longitudinal profile. While the relationship between valley and channel parameters has previously been researched, establishment of the diverse conditions in trough formation enables better understanding of the basin/riverbed relationship. Our research is based on field measurements of representative sections of nine segments defined by changes in the longitudinal profile. The field measurements were performed in autumn months during a low water period to ensure the best conditions for repeated measurements. Significantly, as much as $75 \%$ asymmetry of the measured flow encourages the assumption of strong tectonic influence on the riverbed formation. While the difference between the assumed continuous changes of measured parameters and the actual measured or evaluated parameters remains a matter of interpretation, the detected anomalies enable interpretation of the parameters' relationships. The river bed and the valley morphological parameters were evaluated on the model of The Olšava River basin which drains the eastern part of the Košická kotlina Basin (the Toryská pahorkatina Upland). The location of the basin at the foot of the Slanské vrchy Mts. is an important factor in the formation of the river network asymmetries. Both the Neogene contact between the Slanské vrchy Hills neo-volcanites and the Toryská pahorkatina Upland and the neo-tectonics influenced the change in morphological parameters in the valley's longitudinal and transverse profile and the Ol'šava river bed. Our terrain works comprised length and width measurements of the bars, their positions in the river bed, the width and depth of the channel and the type of section riffle. Available maps enabled calculation of the following; ratio of valley height to width, average gradient of the section, stream gradient index, average channel segment slope, the degree of sinuosity and the highest observed correlation between slope, river segment type (0.9576) and the width and type river reach $(-0.9089)$. High correlation coefficient values were recorded for the valley height and width ratio, the type of river section, the water area and the total river bed width and area.

KEY WORDS: OI’šava catchment, longitudinal profile, deposit forms, hydro-morphological parameters, tectonics

Corresponding author: Dušan Barabas, dusan.barabas@upjs.sk

\section{Introduction}

Morphological exploration of riverbeds is an important prerequisite for understanding erosion causes and transport and deposition processes in the riverbed's longitudinal and transverse profiles. Knowledge of these processes is important from the theoretical, hydro-biological and technical view points, and one source of this information is the ever-increasing flow channels which prevent flooding during increased flows. Moreover, the specifics of individual flows and 
their segments are often overlooked when modifications are designed.

Hydro-morphological research began with Horton (1945), who concentrated on fluvial geomorphology as a complex issue. Thus, channel morphometry as a supplement to hydro-biology was the starting point for calculating hydraulic parameters of the river channel (Horton 1945, Schumm and Lichty 1965, Rosgen 1994 and Łyp 2012). This was followed by unsystematic hydro-morphological research in the 1950's-60's, and formalised study then began in the former Czechoslovakia with the regulation of river torrents (Binder 1950, Krešl 1959, Ferulík 1964). While significant work was undertaken in fundamental analysis of hydro-morphological parameters associated with hydro-biological research, it lacked both comprehensive hydro-morphological research and on-going research of the entire stream; and researchers evaluated only hydro-morphological parameters on selected profiles (Holčík, Bastl 1976, Koščo et al., 2003).

The relationship between the slope of the longitudinal profile and the outlet was then defined by Leopold, Wolman and Miller (1964), and the type of transport in this research was assessed by Schumm (1977) and Rosgen (1994). Based on cross-sectional analysis, Kaszowski and Krzemieň (1999) developed a comprehensive classification of channel reaches and channel types, and identification of changes in the longitudinal profile was determined by Hack (1973) who then defined the relationships required to calculate the stream length-gradient index (SL).

This was followed by Keller's (1986) assessment of basin shape, and this provided the impetus for examining the tectonics which are so important in influencing longitudinal channel profiles. The relationship between tectonics and rivers' longitudinal profile was then analyzed by Bull, McFadden (1977), Hack (1973), Demoulin (1998, 2011), Zuchiewicz (1998), Holbrook, Schumm (1999), Burbank and Anderson (2001), and Bull (2007).

Crosby and Whipple (2006) and Roy and Sahu (2015) examined the factors affecting tectonics, lithology and river formation of knickpoints and tributaries, and this issue became the centre of attention in Slovakia at the turn of the $21^{\text {st }}$ century (Lehotský, Grešková 2005). The Slovak distribution of sediments in longitudinal and transverse profiles was researched by Barabas, Sýkorová (2007), Barabas (2008), Kidová et. al. (2016) and Barabas et. al. (2017), and detailed mapping of the channel and the floodplain was made by Anstead and Barabas (2013). Finally, Škarpich et al. (2013) and Škarpich and Hradecký (2013) investigated features of the Paleogene Moravskoslezské Beskydy Mts. in the Czech Republic.

This current work analyses the causes of changes in selected hydro-morphological parameters of the Slovak Ol'šava River and their impact on the formation of deposits in the river channel. The asymmetry of the river system, where the left tributaries are more developed than the right, is an interesting feature of the river catchment and this is of utmost important because it strongly affects the intensity and spatial structure of deposited processes. Based on work by Zámolyi et. al. (2010) and Jacques et. al. (2014), it is considered that neotectonics affected the formation of the longitudinal and transverse channel and valley profile, and also the intensity of deposition.

\section{Hydrogeographic settings of the Ol'šava River basin}

The study area comprises the Ol'šava River catchment at the border of the Košická kotlina Basin and the volcanic Slanské vrchy Mts. in Slovakia (Fig. 1). The catchment directions and boundaries are as follows; in the east it runs along the main ridge of the Slanské vrchy Mts.; in the north it runs onto the fork of highest peak of the Šimonka mountains at $1092 \mathrm{~m}$ a.s.l.; in the west it traverses the Toryská pahorkatina Upland, to the Nižná Myšl'a village and the southern watershed then passes the drab crotch of the Bradlo Hill at $836 \mathrm{~m}$ a.s.l.

The altitudes range from $173.9 \mathrm{~m}$ to 1092 $\mathrm{m}$ a.s.l, with mostly $917.5 \mathrm{~m}$ a.s.l. The Slovak Hydrometeorological Institute (1988) defines the total catchment area at $339,544 \mathrm{~km}^{2}$ and basic 1:10,000 maps establish that the total length of the river network is $376.4 \mathrm{~km}$. The calculated river network density is $1.11 \mathrm{~km} \mathrm{~km}^{-2}$ and this corresponds with the average density flows in Slovakia.

The Ol'šava source is in the Chabzdová Hill neo-volcanic formations at $775 \mathrm{~m}$ a.s.l. and its 


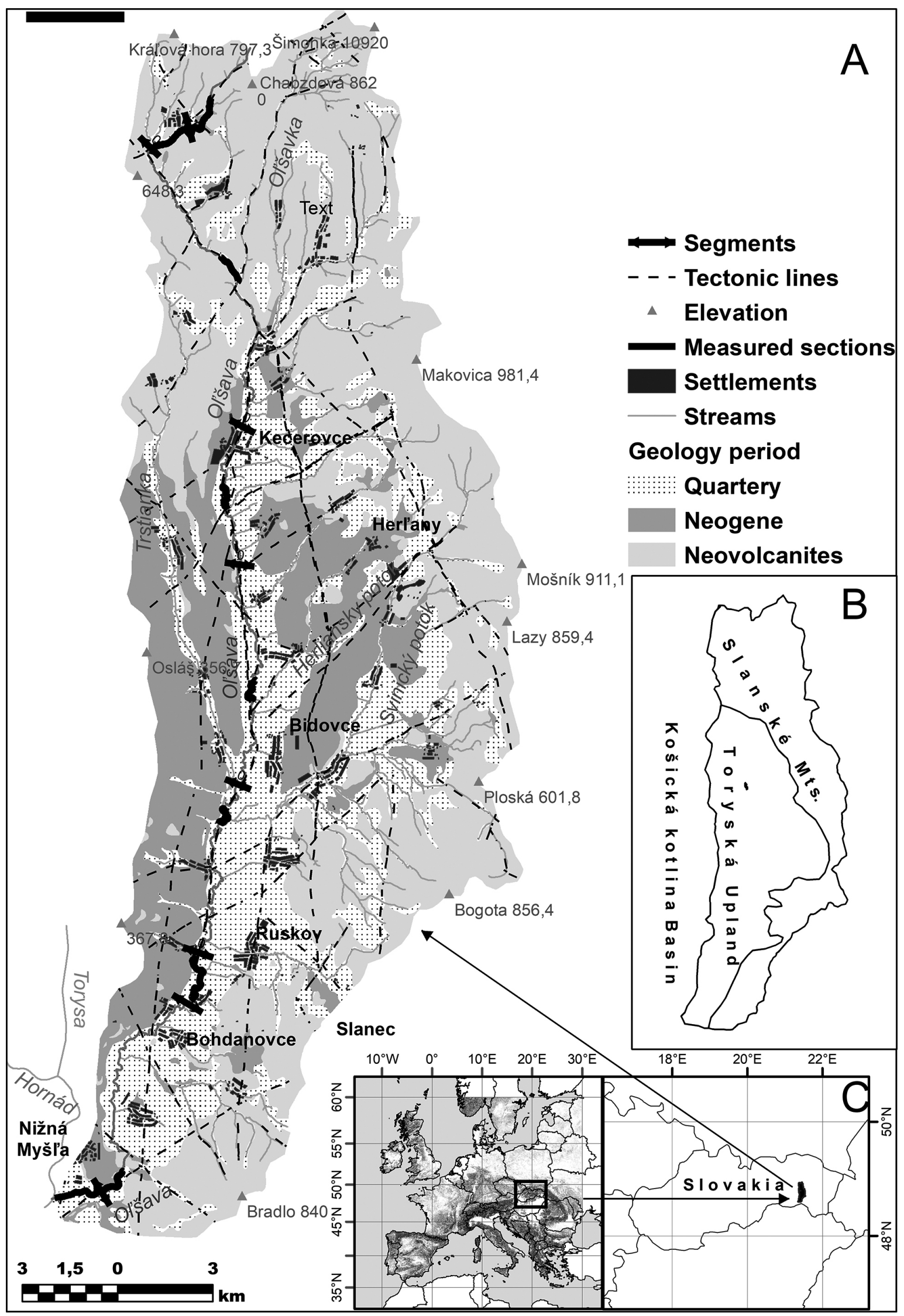

Fig. 1. Geological and tectonic structure of the Ol'šava river catchment (A), geomorphological units of the Ol'šava catchment area (B), the location of the basin $(\mathrm{C})$. 
general southern progress enables inflow to the Hornád River south of the 173.9 m a.s.l. Nižná Myšla village. The altitude difference between the source and river mouth reaches 601.1 metres, with average $0.634^{\circ}$ slope. The entire Ol'šava river system is significantly asymmetrical; where the left catchement constitutes $75 \%$ of the total river catchment area. While the $19.1 \mathrm{~km}$ Trstianka is an important right side tributary, most tributaries drain water from the Slanské vrchy Mts. western hillsides. The most important tributaries are the Svinický potok Creek $(17.3 \mathrm{~km})$, the Herliansky potok Creek $(10.7 \mathrm{~km})$ and the Ol'šavka stream $(9.9 \mathrm{~km})$. In addition, the strato-volcano Slanské vrchy Hills forming the Ol'šava River eastern watershed significantly influence the Ol'šava because they determine an eccentric radial river network deformed by exogenous factors. However, the Olšavka river nature is preserved, and this is best seen close to the Mošnik, Bogota and Lazy Peaks (Fig. 1).

The historical development of the region along the Ol'šava required interventions which affected both the river as a fundamental axis of the catchment and also its tributaries. State maps at 1:10,000 scale detail the drastic $42.4 \mathrm{Km}$ reduced river length from that depicted in the AustrianHungarian Empire II military maps.

\section{Geological and geomorphological settings}

The Ol'šava river catchment has two different geo-morphological units: the Slanské vrchy (Mountains) at $900 \mathrm{~m}$ elevation and the $1092 \mathrm{~m}$ a.s.l. highest point at Šimonka. The Košická kotlina basin catchment, spatially delineated and defined by Mazúr and Lukniš (1980), ranges from 160 to $384 \mathrm{~m}$ a.s.l. (Fig. 1). These units are also geologically different because the Košická kotlina Basin is a tectonic-erosional graben formed in the Low Miocene (Lukniš 1972). The tectonic faults and ruptures system differentiated the catchment and consequently influenced the formation of the river network. In contrast, the upper Ol'šava river catchment is based on andesite pyroclastic rocks, and the Toryská pahorkatina Upland is formed from polymict gravels with loams and claystones of the Varhaňovské štrky (gravels) in the Upper Badenian to Lower Sarmatian.
This geological area generated conditions for landslides formation. One example is the frontal stabilised landslides identified in tributary sub-catchments. These include the Trstianka tributary, one near Bohdanovce and another on the bank of the Ol'šava catchment (Kaličiak et al. 1991, 1996).

The Slanské vrchy Mts. were formed from a sequence of the following considerably eroded strato-volcanoes; the Bradlo, Hradisko, Bogota (Kalinčiak 1996), Mošnik, Makovica and Zlatobanský (Kaličiak et al. 1991). While Koštálik (1988) consider that these could have reached altitudes of $2000-4000 \mathrm{~m}$ a.s.l, the mountains are elevated along longitudinal faults. Additional tectonic evidence is apparent in the deep creek gaps, faceted slopes and very straight foothill lines. Disruption-lines in the transverse direction are also clear in the saddlebacks near Slanec and Ruskov villages, and the volcanic rocks lying on soft sediments of the neogene loamy and shale formation create conditions for block landslides (Lukniš et al. 1964).

The contemporary hydro-geographic network began formation in the Late Miocene; mostly in the Sarmatian and Pannonian (Mazúr 1963). However, the main morphological setting of the Košická valley basin catchment was formed in the Pliocene, and this contained the Ol'šava river valley. The relative tectonic stability of the Upper Pliocene then induced a planation surface which formed the catchment bed, and this was later excised by the river network in the Quarternary (Karniš, Kvitkovič 1970, Maglay et al. 1999). The alternation of climate conditions in the Quarternary caused terrace formation, including the Würmian deposited terraces in Nižná Myšl'a and the Younger and Older Riss glacial erosion-deposited terraces north of Bohdanovce (Janočko 1987).

The terraces surrounded and preserved the edge of the Ol'šava left bank floodplain but those on the right bank of the floodplain are preserved only in fragments north of the Trstianka inlet to the Ol'šava river. This was caused by gradually pushing the Ol'šava river and its tributaries to the west and it resulted in denuded material terraces (Maglay et al. 2011, 1:200 000 map scale).

The maximum width of the Ol'šava floodplain is one kilometre where the Toryská pahorkatina Upland in the Ol'šava valley transits to the 
flat relief plains of the river floodplain catchments (Kalinčiak 1996). The Toryská pahorkatina Upland range is formed from polymict gravels with loams and claystones of the Varhaňovské štrky (gravels) in the Upper Badenian to Lower Sarmatian separates the Olšava floodplain, and the Torysa River was formed in the Quaternary. Alluvial fans then formed at the foothills of the Slanské vrchy Mountains where the vertical gradient of the Ol'šava tributaries markedly decreases (Janočko 1984, 1987; Kalinčiak 1996). Finally, the Ol'šava, Torysa and Hornád river floodplains merge into a $2-5 \mathrm{~km}$ wide floodplain near the inlets of the Ol'šava and Torysa rivers to the Hornád.

\section{Methods}

We initially defined changes in the Ol'šava valley longitudinal profile from contour maps at 1:10,000 scale. This profile curve does not reach the ideal course theoretically approaching the parabola which documents the balance between erosion and deposits (Lehotský 2004) (Fig. 2). However, changes over the longitudinal profile enabled the differentiation of nine relatively homogeneous segments and approximately homogeneous parameters for stream slope, lithology and the valley longitudinal and transverse profiles (Fig. 2). We then measured and evaluated at least $1 \mathrm{~km}$-long-areas of the 11.6 total length of the sections mapped in field work (Fig 1). The measurements began at the confluence of the more significant tributaries and covered the measured segments most technically accessible. Data derived from our field mapping and for segments processed from the 1:10,000 map provided the basic characteristics of the segments listed in Table 1.

Field section measurements were performed in October 2011 when there was minimal change in stream and water level. The measured parameters were evaluated at main intervals of $100 \mathrm{~m}$ and we then measured stream depth at the deepest point and the width of the wet channel at the end points of these $100 \mathrm{~m}$ segments. Finally, the riffle/pool and step/pool river lengths in the segments were measured as in Montgomery and Baffington (1998).

Deposits was measured as the maximum length in the direction of the maximum surface velocity streamline and the maximum width perpendicular to this streamline. The following equation approximated the channel bar area $-P$ :

$$
P=\sum(a \times b) .
$$

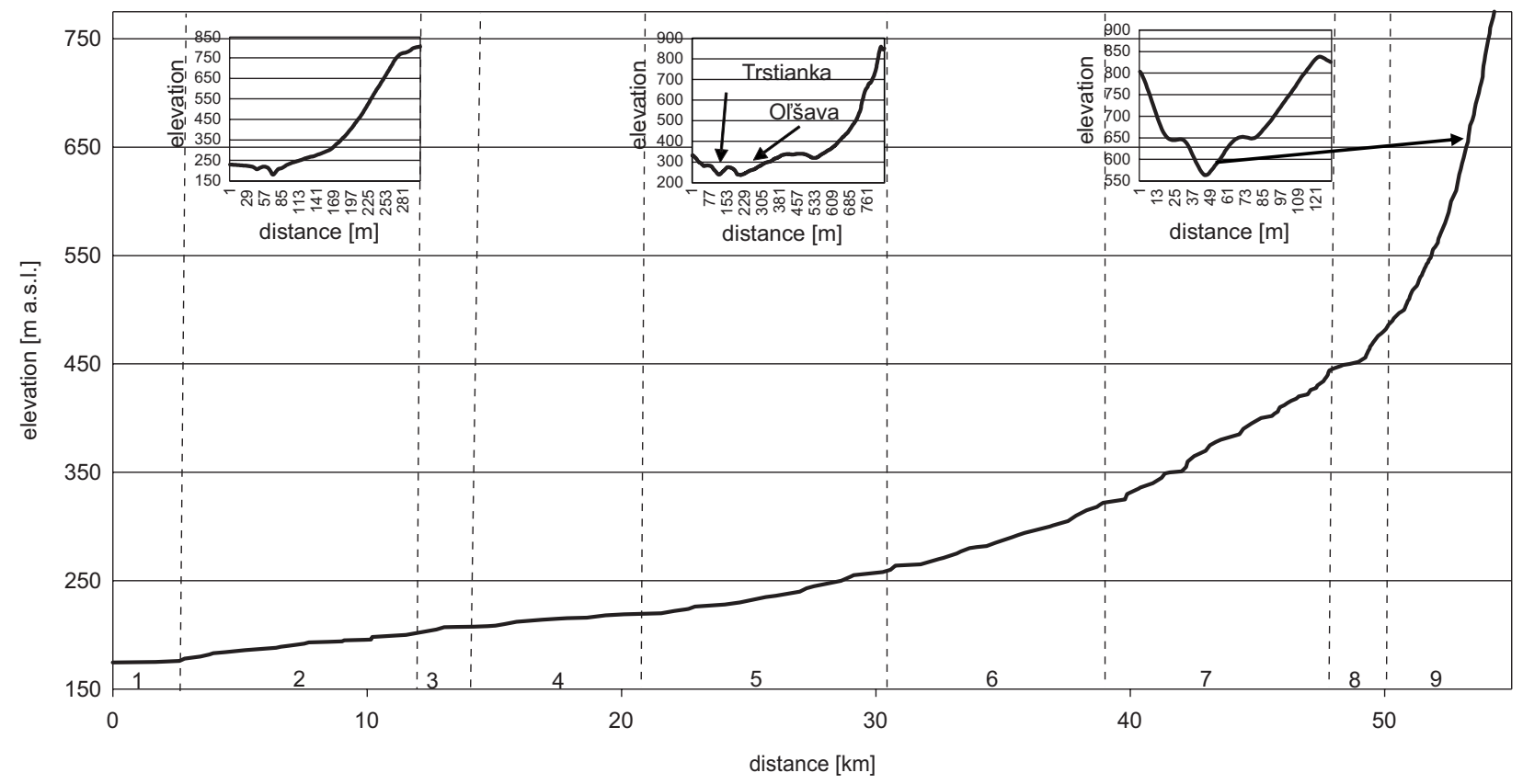

Fig. 2. The longitudinal profile of the Ol'šava river valley showing the boundaries of the assessed segments. The top of the figure depicts transverse profiles of the Ol'šava valley documenting the change in the width of the valley and its asymmetry. 
Table 1. Basic parameters of evaluated segments of the longitudinal profile of the Ol'šava River.

\begin{tabular}{|c|c|c|c|c|c|c|c|c|c|}
\hline \multirow{2}{*}{ segments } & \multicolumn{2}{|c|}{$\begin{array}{l}\text { altitude } \\
\text { [m a.s.1.] }\end{array}$} & \multirow{2}{*}{ lenght } & \multirow{2}{*}{$\begin{array}{l}\text { hight/width } \\
\text { valley (Vf) }\end{array}$} & \multirow{2}{*}{$\begin{array}{c}\text { stream } \\
\text { lenght } \\
\text { gradiet } \\
\text { index (SL) }\end{array}$} & \multirow{2}{*}{$\begin{array}{c}\text { average } \\
\text { slope seg- } \\
\text { ments } \\
{[\%]}\end{array}$} & \multirow{2}{*}{$\begin{array}{c}\text { width } \\
\text { valley } \\
\text { [m] }\end{array}$} & \multirow{2}{*}{$\begin{array}{l}\text { average } \\
\text { slope seg- } \\
\text { ments } \\
{\left[^{\circ}\right]}\end{array}$} & \multirow{2}{*}{$\begin{array}{c}\text { sinuosity } \\
\text { index }\end{array}$} \\
\hline & $\min$ & $\max$ & & & & & & & \\
\hline 1 & 174.5 & 175.0 & 1675.9 & 5.19 & 15.96 & 0.0298 & 384.16 & 0.01707 & 1.030 \\
\hline 2 & 175.0 & 200.0 & 9856.3 & 1.59 & 121.02 & 0.2536 & 241.02 & 0.14530 & 1.495 \\
\hline 3 & 200.0 & 207.3 & 1490.9 & 6.17 & 204.43 & 0.4896 & 1237.46 & 0.28052 & 1.042 \\
\hline 4 & 207.3 & 222.0 & 9051.8 & 3.43 & 59.91 & 0.1624 & 1318.80 & 0.09305 & 1.604 \\
\hline 5 & 222.0 & 265.0 & 9686.5 & 5.33 & 121.62 & 0.4439 & 1060.46 & 0.25430 & 1.569 \\
\hline 6 & 265.0 & 305.0 & 5795.1 & 2.26 & 135.67 & 0.6902 & 550.25 & 0.39550 & 1.212 \\
\hline 7 & 305.0 & 456.0 & 11692.2 & 0.26 & 140.93 & 1.2915 & 53.00 & 0.73990 & 1.296 \\
\hline 8 & 456.0 & 504.0 & 1596.7 & 0.08 & 128.31 & 3.0062 & 10.00 & 1.72191 & 1.112 \\
\hline 9 & 504.0 & 774.0 & 3469.7 & 0.15 & 135.00 & 7.7817 & 20.00 & 4.44960 & 1.056 \\
\hline
\end{tabular}

The total channel area $P_{V}$ was calculated by the following equation; where $H$ is the width of the stream:

$$
P_{V}=100 \times H
$$

The channel water level surface area $\Delta S$ was calculated as the difference of the total riverbed area $P_{V}$ and the total area of bars $\Delta S_{P L}$ :

$$
\Delta S=P_{V}-\Delta S_{P L}
$$

The $K$ coefficient is the ratio of the area of the stream channel water level $\Delta S$ to the area of bars $P$ :

$$
K=\Delta S / P .
$$

The stream length-gradient index $S_{L}$ was calculated to evaluate the stream slope; as in Hack (1973):

$$
S_{L}=\frac{\Delta H}{\Delta L} \times L=\frac{H_{\max }-H_{\min }}{\Delta L} \times L .
$$

The difference in altitude of the initial $H_{\min }$ and $H_{\max }$ of segment point $\Delta L$ equals the evaluated segment length $L$ from the source to the middle of the reported segment.

Average percentage slope $S$ of the measured segment was calculated by:

$$
S=\frac{\Delta H}{\Delta L} \times 100 \%
$$

The valley height/width ratio $S V_{f}$ evaluated the valley cross-section; as in Keller (1986):

$$
V_{f}=\frac{2 V_{f w}}{\left(E_{L D}-E_{S C}\right)+\left(E_{R D}-E_{S C}\right)} .
$$

The information to calculate this parameter was ascertained by an axis drawn through the middle of each longitudinal profile segment on the 1:10,000 base map. The line is perpendicular to the Ol'šava stream; where $V_{f w}$ is part of this line and is the width of the valley bottom; $E_{L D}$ is the altitude of the left watershed; $E_{R D}$ is the altitude of the right watershed and $E_{S C}$ is the altitude of the valley floor.

The sinusoity index was calculated as the quotient of the median line of the stream and the direct distance of the segment end-points (Pišút, Tomčíková 2008). The channel width/depth index was then calculated as the quotient of these parameters.

Synthesis of expected impacts enabled monitoring the effect of potential energy changes on segmental deposition. Concurrently, the sedimentation processes in the river-bed were mainly affected by short-term potential energy changes occurring over several decades.

\section{Morphometry of measured longitudinal profile sections}

Slope is the basic parameter defining the stream's longitudinal profile, and changes in slope value affect the kinetic energy of the stream. This is reflected especially in changes in the depth and width of the stream, and in all other evaluated parameters (Rosgen 1994, Schumm 1977). The basic morphometric channel depth/width index from the river mouth to the source is declining, 


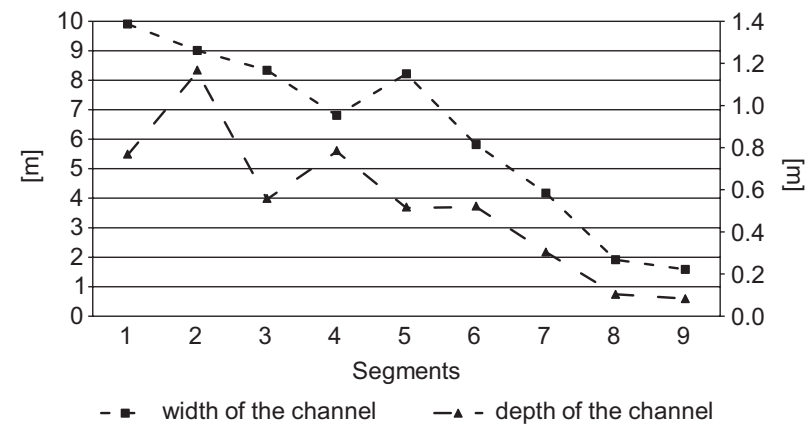

Fig. 3. The average width of the riverbed (left axis) and the depth of the channel (right axis) in the measured Ol'šava River longitudinal profile section.

and anomalies are apparent in the Ol'šava river section 4 width analysis. A significant decrease in the average width of the river-bed is obvious in the 1st section and is related to anthropogenic modification of the river mouth, and 3rd section loss is connected with neo-tectonic effects (Maglay et al. 1999). Channel down-cutting also reduced the channel width, and this affected the total river-bed deposits area (Figs 3, 5).

The following Ol'šava River segment differences were also noted; there is increased bar area in segment 6 due to rapid slope decrease; where section 6 has $0.4^{\circ}$ and section $7,0.74^{\circ}$, and stream kinetic energy there created conditions for increased sedimentation (Fig. 4). Anomalies in reversed changes in width variation and deposits were then observed in segments 2 and 4 , and there is marked increase in river bench areas in the 2nd segment with increased river-bed width. There is also incision in this section, where tectonic lines epigenetically cut-off part of the Slanské vrchy Hills east of Nižná Myšl'a village (Dzurovčin 1989) (Fig. 1). Section 4 has increased river channel width and less bar surface area.

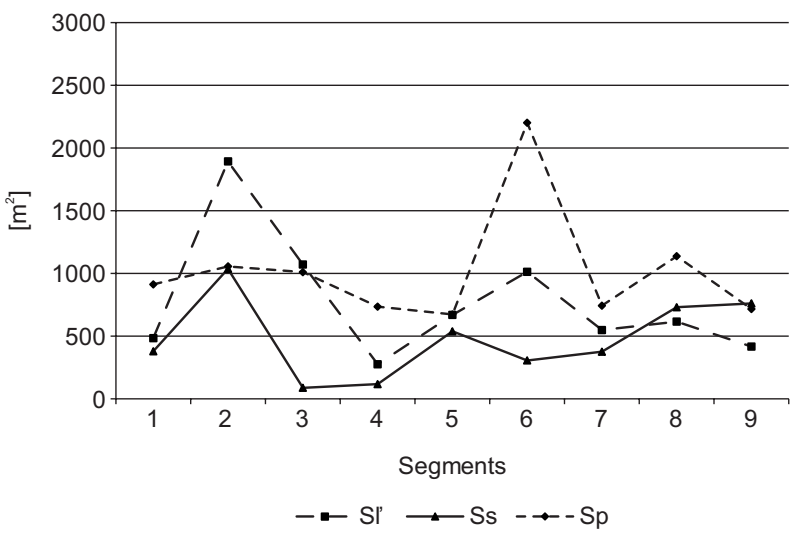

Fig. 4. Bar areas on the left (Sl'), centre (Ss) and right side (Sp).
This section is moderately subsiding; most likely due to neo-tectonics (Maglay et al. 1999) and it is also affected by increased discharge from the most significant Trstianka stream and Svinický potok Ol'šava tributaries (Fig. 1). The Ol'šava is narrowest in this part of the catchment, where it cuts off the mouth of the extensive Svinicky potok proluvial fan. This brook primarily follows the tectonic fault-line connecting the transverse faults affecting both the Ol'šava river's longitudinal profile slope and river-bed width (Kaličiak et al. 1991 and Fig. 1 herein). Further tectonic elevation between the Bidovce and Herl'any villages induced Neogene tectonic movements cut by the Ol'šava River, and this resulted in the widest and deeper channel in section 5. (Pospíšil, Husák 1985).

Combined tectonics, consequent riverbed geological structure and catchment formation affects bar distribution in the Ol'šava longitudinal profile, and this is important for material distribution (Fig. 4). The combination also induces the strong catchment asymmetry manifested in deposition intensity. Analysis of the deposited areas reveals the surprising superiority of right-sided bars over the left, because although the great stream asymmetry results in material deposition, it is mostly left-side tributaries which push the Ol'šava river westward. This is evident in the position of the stream and the presence of the

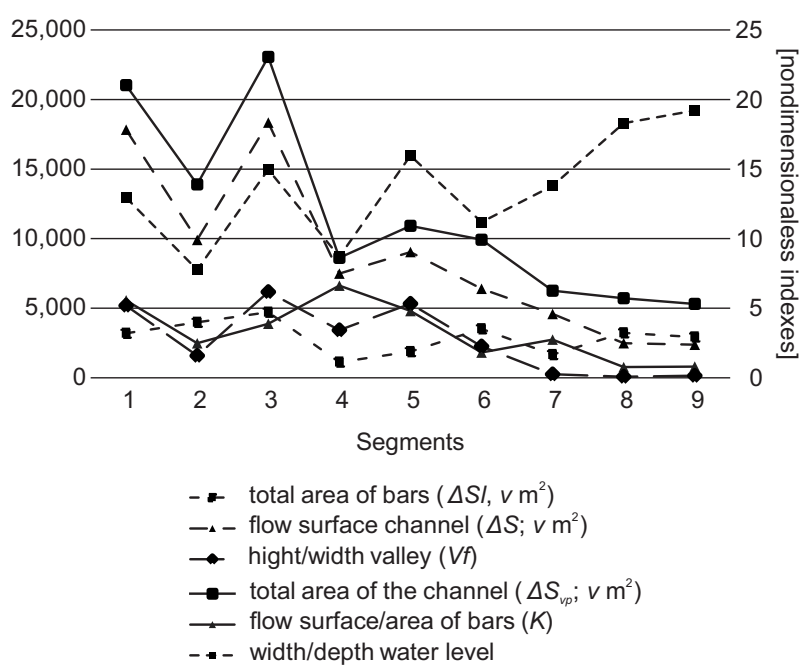

Fig. 5. Graph of individual parameters in the Ol'šava flow measured section.

Left axis: total area of bars $\Delta S l\left[\mathrm{~m}^{2}\right]$, total area of the channel $\Delta S_{v p}\left[\mathrm{~m}^{2}\right]$, flow surface channel $\Delta S\left[\mathrm{~m}^{2}\right]$. Right axis: height/width valley $V f$, width/depth water level, and flow surface/area of bars $K$. 
Quaternary sediments (Fig. 1). The right-bank deposits may therefore result from a relatively stable stream meandering in its own sediments and forming right-sided channel flow deposits .

While we acknowledge the permanent Ol'šava shift by left-side tributaries, this should have generated intense left-bank deposition and right-bank lateral erosion. This continuous process in its extreme form then shaped the Ol'šava River channel with its current significant catchment asymmetry. Dzurovčin (1989) also emphasised similar results in Burbank, Anderson (2001), and fiurther researchers registered an Ol'šava river terrace of large platforms formed especially on the left bank of the catchment area (Janočko 1987, Bull 2007). In contrast, there was only a narrow strip of similar terraces preserved on the catchment's right.

Although only segment 2 of the longitudinal priofile confirmed our expectations of containing the largest area of left-side bars, this section also had the most typical alternating source-area phenomena. Segment 2 also had obviously increased area of central bars which decreases in sections 3 and 4 , increases again in section 5 and attains its maxima in sections 8 and 9. This sedimentary process corresponds with results in other streams (Barabas, Sýkorová 2007, Barabas 2008, Barabas et. al. 2017), and is most likely related to excess material rising from intensive depth and causing lateral erosion in the stream headwaters' higher flow rates and ultimately shaping the channel (Rosgen 1994).

It is remarkable that the $57: 43 \%$ right/left side deposits ratio is reversed to $25: 75 \%$ in the catchment area. Deposition also decrease between sections 3 and 5, and this is most likely related to the neotectonic and slope changes which created conditions for increased segment meandering in its own sediments. This ultimately gave a higher sinuosity index value and a lower river-reach due to rifle and pool-type configuration (Fig. 6). Moreover, the Ol'šava River flow in sections 2, 3, 5 and 6 is pressured by significant left-sided tributaries towards the Toryska pahorkatina Upland slopes; thus enabling increased material deposition on the left side. Tectonic faults and Olšava Valley asymmetry also influence this deposits, and the Slanské vrchy Mts. Ol'šava sections 8 and 9 flow on the left side of the valley. This is finally manifest in increased deposition on the right side of the channel and eventual central deposition.
The decrease in total river-bed area from river-mouth to source is considered normal, and here the total channel area decreases unevenly (Fig. 5). This anomaly is attributed to section 2, where channel area decreases significantly from edge epigenesis which prevents channel widening. (Dzurovčin 1989). This is then succeeded by section 3's different phenomenon of significant channel increase which corresponds to changes in evaluated parameters. While these include valley ratio index, channel width and depth indices and the stream's channel flow surface area and gradient index, the primary causes are valley height/width ratio, average segment slope and flow rate and stream index (Figs 5, 6).

Changes in the remaining parameters prove only consequential. There is slight increase in channel area in section 5 because of valley and floodplain enlargement (Fig. 1). Stream meander is also strong there, with sinuosity index between 1.5 and 1.6 and several large river islands formed with overgrown permanent vegetation of poplars, willows, alders and oaks. There is then continuous decline in total river-bed area in section 6 where anomalous flow is caused by increased sediment deposits from anthropogenic channel work above the Kecerovce village measuring points. This is followed by significantly higher average slope in segments 7,8 and 9, where the stream is largely eroded and material was transported to segment 6 to produce its river-bed decrease and from there to the Slanské vrchy Mts. This material accumulation passes down the Toryska pahorkatina Upland valley's

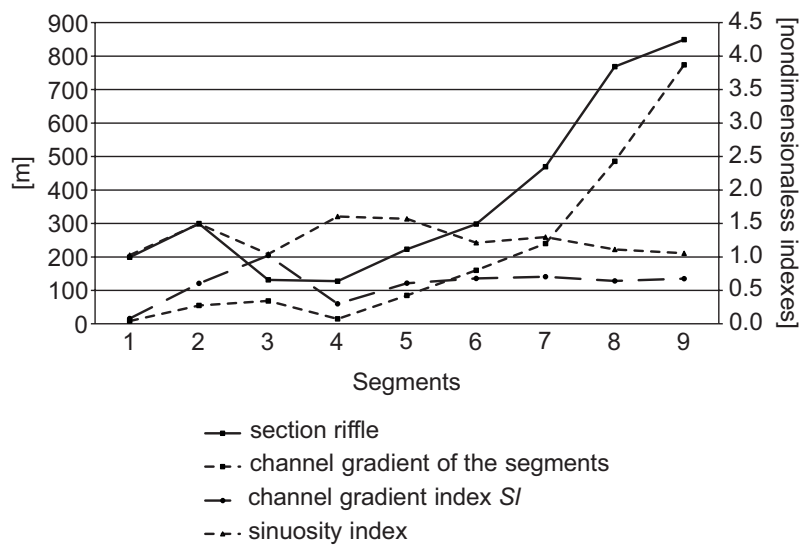

Fig. 6. Graph of the different parameters in the Ol'šava measured section.

Left axis: section riffle type [m], channel gradient index SL. Right axis: average channel segment slope and degree of sinuosity. 
longitudinal profile slope. The Ol'šava river-bed deposited material then increases with the type of river reach step/pool in the final two sections; 8 and 9 (Montgomery, Baffington 1998, Lehotský, Grešková 2005).

Overall, the Ol'šava is deeply eroded, and thicker transported materials accumulate in channel areas with greater slope. Segment 7 therefore forms a transition segment with geological basechange and knickpoint. However, for best interpretation and understanding of the complexity of channel-forming processes, it is most useful to employ the synthetic parameters previously discussed for deposits interpretation.

While Figure 5 establishes that the flow surface channel area diagram is almost identical to the graph of the total channel area, the decrease towards the source is less evident. Increase in channel flow area from section 3 to 5 is obvious, and this determines the increase in the width of the entire valley and highlights that the valley is widest in these sections; 3 to 5 These values then significantly decrease towards the source. Moreover, section 6 has bar deposit areas which exceed the flow surface channel area when the river loses power to transport this material through the transition from the sharp Slanské Hills slopes to the extended low-inclined part of the valley. Although there is minimal channel flow-surface area, the deposition flow intensity is striking.

Factor $K$ identifies the extent to which the flow surface channel area, or surface level, exceeds the total area of a segment's bars. When $K$ has higher values, the flow channel area is larger than the bar area; eventually resulting in less intense deposition. This is significantly manifested in the $2^{\text {nd }}$ section where the slope begins to increase. Similar to Section 6, there is a greater abundance of river-reach riffle and pool sections here, a narrow valley with lower height/width ratio, a narrow, deep channel trough and decreased channel width and depth. However, the $K$ coefficient is greatest in section 4 , where the total bar area is small and this widest part of the valley has a small height/width ratio and the accompanying relatively deep and narrow trough indicates a low channel width/depth index; similar to the chacteristics noted in section 7 .

Hack (1973) recorded that stream gradient index is a theoretically calculated parameter indicating slope changes, and figure 6 herein highlights notable anomalies in segments 3 and 4 where index changes correspond to these sections' calculated slope changes. These sections are on the boundary of tectonic uplift and descent and this becomes apparent as an deposited area. In addition, the fall-line index has no significant changes between section 5 and the headwaters, and Figure 6 hightlights that the average segment slope does not change significantly from river mouth to source. Tectonics, however, created an exception in the $4^{\text {th }}$ segment where part of the valley subsides with subsequent high sinuosity index and change in width due to small depositions.

The valley height-width ratio in Figure 5 provides information on the general nature of individual parts of the catchment. Its value indicates the intensity of deposition formation and documents the channel's total area and its flow and width-depth indices. Sections with tectonic-uplift induced stream incision to the river-bed and have values close to zero. The stream reacts with a time-lag dependent on rock resistance and river-bed water volume. The cross-section in Ol'šava Valley segments 2, 7, 8 and 9 is $V$ shaped, and while this indicates prevailing erosional incision, the remaining segments have a wide open valley with transportation and lateral erosion. High valley ratios result from tectonic movements and stream kinetic energy, and here the watershed divide to the Ol'šava left is much higher than on the right.

It was difficult to accurately determine the watershed divide in the $1^{\text {st }}$ segment because this area descends relatively evenly to the bottom of the Košice Basin, and the boundaries between the Ol'šava River and adjacent Hornád tributaries are hard to distinguish. This segment has maximum height and consequent high height-width ratios where the Ol'šava River flows into the Hornád. Meanwhile, the second segment has significantly decreased valley width-depth ratio as the Olšava cuts a channel through the remnants of pyroxenic andesite lava flows (Kaličiak 1996). While the highest valley ratios are evident in segments 2 and 3 , segment 4 has decreased values caused by the elevation of a very wide floodplain and divided left watershed on the Slanské vrchy ridge. Segment 5 then forms the widest part of the Ol'šava River valley and the valley ratios increase until segment 6 where valley narrowing and 
marked increase in ridge altitudes on both sides decrease the ratios (Fig. 5). Figure 5 also highlights that the channel width/depth index graph has identical course to the graph of total channel area up to segment 6 . Thereafter, segments 7,8 and 9 in the upper part of the stream have low banks and shallow channel depth with relative width; and the channel width/depth index therefore has a different course in these segments.

Riggs (1978) records that the sinuosity index does not have smooth decline from the river mouth to the source area (Fig. 6). The higher value $>1.5$ for meandering streams in segments 4 and 5 is related to valley-width and the Ol'šava River channel meandering in its own sediments. Segments 2 and 7 have medium tortuosity, with sinuosity index of 1.26-1.5. This then decreases to 1.06-1.25 in segments 6 and 8 , and segments 1,3 , 9 have direct-type sinuosity index at 1.01 to 1.05 . Based on slope, the length-gradient index in the 3rd segment should be meandering but channel formation induces direct-flow categorisation.

The calculated correlation coefficients in Table 2 can then be divided into two groups; the more important group defines the value between the measured and eventually evaluated parameters of slope, section riffle type, bar areas and channel and valley width/depth ratios.

The second group defines relationships between the derived parameters of water level width/depth index, water/bar area and channel flow surface. Segment slope angle has a crucial role in river-reach typology, and a very close relationship is apparent between channel width and valley width/height ratio, total stream area and channel flow surface. This relationship confirms the influence of overall catchment character on channel formation. Although the calculated correlation coefficients have only small dependence on deposited parameters, a significant negative relationship exists; deposit decreases as sinuosity index increases (Table 2). There is also the relatively high 0.676 correlation coefficient between channel width/depth index and river water movement reaching the riffle/pools. This is due to the relationship between channel depth and width; where increase in one induces decrease in the other. There are also high correlation coefficients in the relationship between average channel width, total riverbed area and the

Table 2. Correlation matrix of the individual Ol'šava flow parameters in the segments of the mapped sections.

\begin{tabular}{|c|c|c|c|c|c|c|c|c|c|c|}
\hline & 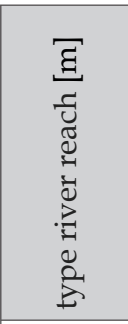 & 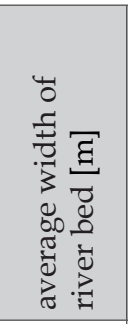 & 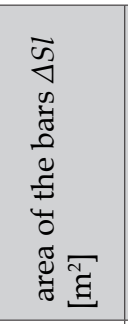 & 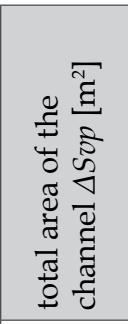 & 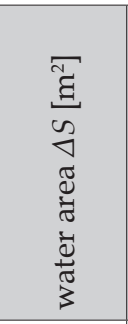 & 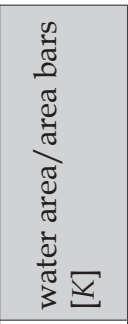 & 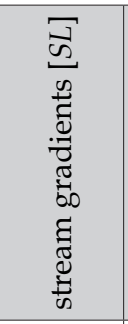 & 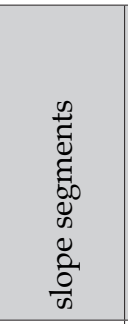 & 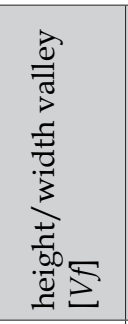 & 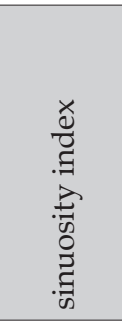 \\
\hline type river reach [m] & - & & & & & & & & & \\
\hline $\begin{array}{l}\text { average width of river- } \\
\text { bed [m] }\end{array}$ & -0.9089 & - & & & & & & & & \\
\hline $\begin{array}{l}\text { area of the bars } \Delta S l \\
{\left[\mathrm{~m}^{2}\right]}\end{array}$ & 0.0004 & 0.3437 & - & & & & & & & \\
\hline $\begin{array}{l}\text { total area of the chan- } \\
\text { nel } \Delta S v p\left[\mathrm{~m}^{2}\right]\end{array}$ & -0.6758 & 0.8196 & 0.5862 & - & & & & & & \\
\hline water area $\Delta S\left[\mathrm{~m}^{2}\right]$ & -0.7447 & 0.8359 & 0.4502 & 0.9873 & - & & & & & \\
\hline $\begin{array}{l}\text { water area/area bars } \\
{[K]}\end{array}$ & -0.8181 & 0.5971 & -0.4002 & 0.4733 & 0.6001 & - & & & & \\
\hline stream gradients $[S L]$ & 0.2060 & -0.0460 & 0.4379 & -0.0413 & -0.1313 & -0.5419 & - & & & \\
\hline slope segments & 0.9576 & -0.9016 & 0.0121 & -0.6263 & -0.6926 & -0.7654 & 0.2821 & - & & \\
\hline $\begin{array}{l}\text { height/width valley } \\
{[V f]}\end{array}$ & -0.8158 & 0.7603 & 0.1637 & 0.8112 & 0.8620 & 0.7471 & -0.1214 & -0.7021 & - & \\
\hline sinuosity index & -0.4078 & 0.2685 & -0.5840 & -0.2729 & -0.1863 & 0.4380 & -0.1873 & -0.4496 & 0.0689 & - \\
\hline $\begin{array}{l}\text { Index width/depth } \\
\text { water level }\end{array}$ & 0.6817 & -0.6568 & 0.0603 & -0.2456 & -0.2827 & -0.4714 & 0.3372 & 0.7426 & -0.1801 & -0.5676 \\
\hline
\end{tabular}

Significant level $=0.05, \mathrm{~N}=9$. 
$K$ coefficient which defines the water/bar area relationship. These three parameters are formula factors in calculating average riverbed width, so the relationship is unsurprising

The average channel width significantly correlates with the average segment slope which increases towards the source, and high correlation also exists between valley height and width and the average riverbed width, total riverbed area, water area and $K$ index. The graph in Figure 5 highlights that similar coursing curves prove this parameter dependence. The valley width/depth ratio rated against other parameters provides the strength of dependence between parameters.

Section 5 clearly shows that the Svinický potok Creek accumulation fan created conditions for Ol'šava incisions. This resulted in a deep narrow channel instead of the expected shallow wide one with different accumulation forms. It is natural that the average channel width correlates with the channel width/depth index because of almost identical input data. This dependency is indirect.

Total riverbed area values strongly correlated with water area values; where increasing bar areas decreased the water area. The total bar area for all sections is relatively stable, with only small fluctuations and therefore the total area and water area values are similar. The correlation of average segment slope and $K$ coefficient are related to changes in the channel width, and width decreases with increasing slope.

The average section slope correlates with the valley height and width and rises towards the source, thus providing inverse values. In addition, the $C$ coefficient has relatively high correlation coefficient with the valley ratios which are uneven in proportion. Indirect dependence is due to increasing trending towards the sources and the decrease in valley aspect ratio noted between valley width and the headwaters fall-line.The relatively high correlation coefficient between the average slope index and channel width/depth index documents the intensity of lateral erosion compared to depth erosion. Concurrently, the segments with lower channel width/depth ratio than neighbouring segments are more prone to flooding.

The sinuosity index has relatively significant indirect dependency on total bar area and channel width/depth index; with the result that this latter index is lower when stream sinuosity index is higher. This provides an incised channel, with lower flood potential. In addition, deposits decreases with increased sinuosity index, and this mutual correlation was most likely induced by human intervention because the streams were previously aligned. This then affected the sinuosity index and consequently the channel width and depth in individual segments. Analysis of evaluated parameters by segment enables division of the 9 segments into 3 groups. Correlation is 0.93 between segments 1 to $4,0.327$ between 5 and 6 and 0.992 for 7 to 9 . This reveals anomaly in Sections 5 and 6 where the parameter correlation is most anthropogenically disturbed.

The SL stream length-gradient index has a higher correlation coefficient than the $K$ coefficient for water/bars area. While both parameters have relatively stable values in all segments, slope and anthropogenic activity have preserved deposit forms in the riverbed. While the $S L$ and valley height/width ratios in segments 7 to 9 follow the same course as Segment 2; all segments share the common break-through feature of narrow parts before reaching the catchment headwaters.

The Ministry of Environment documented the relationship between segment parameter changes and flood frequency (MZP 2011). The highest frequency of floods between 2004 and 2010 occurred in the villages in segments 2,4 and 6 . This significantly correlates with channel width/ depth index; where flooding was more frequent in narrow and deep segments with a low index value and there was little or no flooding in segments with higher width/depth indices.

\section{Discussion and conclusion}

Analysis of the measured and evaluated morphometric parameters revealed very complex relationships in the Olšava River longitudinal profile. The anthropogenically altered river flow courses along significant river-bed asymmetry in a tectonically damaged river basin area. This ensures prerequisites for complex development of the river network and accompanying trough-floating units. Lithology then influenced trough parameters, and this is most noticeable in Section 2 which records sudden change in almost 
all evaluated parameters. Figure 1 highlights the relationship between tectonics and river network, where it is evident that the bulk of the river network has developed into a fault-line system. The asymmetry of the basin is certainly influenced by tectonics, and this is supported by Holbrook and Schum (1999), Burbank and Anderson (2001), Bull (2007), and Roy and Sahu (2015).

When the continuous changes in the measured sections' parameters are considered, each anomaly in the channel's morphometry parameters graphed herein results from individual river basin changes. Moreover, the impact of transverse fractures and other structural-influenced movements can only be identified from trough morphometry. Further, Section 3's rapid parameter changes in sinuosity index, channel gradient, total bar area and water level height/width ratio document the altered development of this section (Figs 5, 6). Maglay et al. (1999) neotectonic map also highlights the up-lift of segments 1,2 , and 3 in the catchment area, with consequent higher channel gradient and less sinuosity, and Burbank and Anderson (2001) and Zámolyi et al. (2010) add that these changes are further enhanced by anthropogenic adaptations. Thus, some sinuosity decrease and the coincidental altered trough in segment 3 is occasioned by human intervention.

Additional changes include:

1. significant inflow from the Svinický stream induces section 4 changes in SL flow gradient index (Fig. 6) and also depth increase and trough narrowing (Fig. 3),

2. the transition to Neogene volcanic segments in section 6 accounts for its knick-zone in the Toryská pahorkatina Upland, and it also has over $1 \%$ slope increase and a greater accumulation area deposited at the foot of the Slanské vrchy Mts, and

3. sections $7,8,9$ are in an unevenly elevated part of the basin, where depletion and accumulation processes form a channel-bed proportional to the extensive accumulation width (Maglay et al. 1999).

Historically, the development of this area required interventions that affected both Ol'šava river flow and the baseline of the catchment and the tributaries. These promoted decreased river flow length by $42.4 \mathrm{~km}$; the length of the river network in the basic 1:10,000 map compared to the length in the $3^{\text {rd }}$ military map.
The preservation of the Risky and Würmen aged terraces in the left part of the valley and their absence on the right side corresponds with the flow asymmetry recorded in Holbrook and Schumm (1999), Burbank and Anderson (2001) and Bull (2007). Moreover, despite the expected greater left-hand accumulation forms, there is slight prevalence of right-hand forms, thus contradicting our previous assumptions, but it most likely occurred in stabilisation of the Ol'šava river's longitudinal profile. The stream-flow in its floodplains and the decreased right-bank degradation created evenly rotating material accumulation on both sides of the river-bed. (Fig. 4). This may be proven by the trough's altered position from the torsion of the Toryska pahorkatina Upland in some parts of the river's profile (Fig. $1)$.

Our research established the Ol'šava's flow by measuring all parameters in the 9 individual segments. While this method carries error possibility that can be averted by continuous flow measurements, the immediate length of measurements enables accurate assessment of the segment relationships. Finally, this division into river flow segments has proven a very sensitive technique for comparative parameter measurements throughout the Ol'šava River's profile.

\section{Acknowledgment}

This study was supported by the Scientific Grant Agency: VEGA 1/0963/17 Landscape dynamics in high resolution and VEGA 1/0119/15 Terrestrial laser scanning of urban vegetation for creation of virtual 3-D models of cities and their applications, funded by the Ministry of Education, Science, Research and Sport of the Slovak Republic.

The authors are also indebted to R.J. Marshall for the language correction.

We would also like to thank the reviewers for their insightful and helpful comments on the article.

\section{Author's contribution}

This article is a result of reworking and supplementing the measurements carried out in the framework of the graduation thesis of M. Tkáč. The theme, concept, and writing of the article was realized by D. Barabas. Percentage of work on the article is D. Barabas $60 \%$ and M. Tkáč $40 \%$. 


\section{References}

Anstead L., Barabas D., 2013. Hydromorfologický prieskum Váhu ako nástroj pre manažment vodných tokov na Slovensku. Geographical Journal 65(1): 61-81.

Barabas D., 2008. Analýza priestorového rozšírenia akumulačných foriem v korytových úsekoch Bodvy. Geomorfologia Slovaca et Bohemica 8(1): 7-15.

Barabas D., Bóna J., Klein D., Balážovičová L., 2017. Morphometric and geological conditions for sediment accumulation in the Udava River, Outer Carpathians, Slovakia. Journal of Geographical Sciences 27(8): 981-998. DOI: 10.1007/s11442-017-1416-2.

Barabas D., Sýkorová J., 2007. Akumulačné formy v koryte toku Bodva a ich priestorové rozšírenie. Geomorphologica Slovaca et Bohemica 7(2): 58-64.

Binder R., 1950. Zahrádzanie bystrín. Bratislava: Oráč.

Brierley G., Fryirs, K., 2005. Geomorphology and River Management: Applications of the River Styles Framework. Blackwell Publishing, Victoria, Australia.

Bull B.W., 2007. Tectonic geomorphology of mountains : a new approach to paleoseismology. Blackwell Publishing Ltd.

Bull W.B., McFadden L.D., 1977. Tectonic geomorphology north and south of the Garlock Fault, California. In: D.O. Doehring (eds.), Geomorphology in arid regions. State University of New York at Binghamton: 115-138.

Burbank W.D., Anderson S. D., 2001. Tectonic Geomorphology. Blackwell Publishing, Victoria, Australia.

Crosby B.T., Whipple, K.X., 2006. Knickpoint initiation and distribution within fluvial networks; 236 waterfalls in the Waipaoa River, North Island New Zealand. Geomorphology 82: 16-38.

Demoulin A., 1998. Testing the tectonic significance of some parameters of longitudinal river profiles: the case of the Ardenne (Belgium, NW Europe). Geomorphology 24: 189_ 208.

Demoulin A., 2011. Basin and river profile morphometry: a new index with a high potential for relative dating of tectonic uplift. Geomorphology 126: 97-107.

Dzurovčin L., 1989. Morfológia vulkanických telies v strednej časti Slanských vrchov. Geographical Journal 41(2): 226-233.

Ferulík J., 1964. Lesotechnické úpravy na hornom Považí. In: Materiály ku konferencii o LTM. Zvolen: VÚLH.

Hack J. T., 1973. Stream-profile analysis and stream-gradient index. Journal of Research of the U.S. Geological Survey 1(4): 421-429.

Holbrook J., Schumm S.A., 1999. Geomorphic and sedimentary response of rivers to tectonic deformation: a brief review and critique of a tool for recognizing subtle epeirogenic deformation in modern and ancient settings. Tectonophysics 305: 287-306.

Holčík J., Bastl I., 1976. Ecological effects of water level fluctuation upon the Fish population in the Danube river floodplain Czechoslovakia. Acta scientiarum naturalium, Brno 10(9): 1-46.

Horton R. E., 1945. Erosional development of streams andtheir drainage basins, Hydrophysical approach to quantitative morphology. Geological Society of America Bulletin 56: 275-370.

Jacques D.P., Salvador D.E., Machado R., Grohmann H.C., Nummer R.A., 2014. Application of morphometry in neotectonic studies at the eastern edge of the Paraná Basin, Santa Catarina State, Brazil. Geomorphology 213: 13-23. DOI: 10.1016/j.geomorph.12.037.
Janočko J., 1984. Kvartérne sedimenty. In: Vysvetlivky ku geologickej mape ČSSR 1:25 000, list 38-131, Sečovce-1. Archív GÚDŠ Košice.

Janočko J., 1987. Kvartérne sedimenty západných svahov severnej časti Slanských vrchov a ich podhoria. MS. Archív GÚDŠ Košice.

Kaličiak M., 1996. Geomorfologické členenie. In: M. Kalinčiak (eds.), Vysvetlivky ku geologickej mape Slanských vrchov a Košickej kotliny - Južná čast'. Bratislava (GS SR): 8-11.

Kaličiak M., Baňacký, V., Janočko J., Karoli S., Petro L'., Spišák S., Vozár J., Žec B., 1996. Geologická mapa Slanských vrchov a Košickej kotliny, Južná čast'. Bratislava (GS SR).

Kaličiak M., Jacko S., Janočko J., Karoli S., Molnár J., Petro L., Spišák S., Vozár J., Žec B., 1991. Geologická mapa Slanských vrchov a Košickej kotliny, Severná čast'. Bratislava (GÚDŠ).

Karniš J., Kvitkovič J., 1970. Prehl'ad geomorfologických pomerov východného Slovenska. Bratislava (SNP).

Kaszowski L., Krzemieň K. 1999. Classification systems of mountain river channels. Prace Geograficzne IG UJ 104, 27-40.

Keller A. E., 1986. Investigation of Active Tectonics: Use of Surficial Earth Processes. The National Academy Press. Washington DC: 136-147.

Kidová A., Lehotský M., Rusnák M., 2016. Geomorphic diversity in the Braided-wandering Belá River, Slovak Carpathians, as a response to flood variability and environmental changes. Geomorphology 272: 137-149. DOI: 10.1016/j.geomorph.2016.01.002.

Koščo J., Lusk S., Halačka K., Lusková V., 2003. The expansion and occurrence of the Amur sleeper (Perccottus glenii) in eastern Slovakia. Folia Zoologica 52(3): 329-336.

Koštálik J., 1988. Morfogenéza Slanských vrchov a jej význam pre ochranársku prax. XII. Východoslovenský tábor ochrancov prírody 1988. In: Prehl'ad odborných výsledkov. Prešov ONV odbor kultúry, Slovenský zväz ochrancov prírody a krajiny okresný výbor, Krajský ústav štátnej pamiatkovej starostlivosti a ochrany prírody: 10-24.

Krešl J., 1959. Vliv lesnatosti povodí na odtok. Sborník ČSAV, Lesnictoí, 7: 135-142.

Lehotský M., 2004. Hodnotenia morfológie vodných tokov. Geomorphologia Slovaca IV(1): 36-47.

Lehotský M., Grešková A., 2005. Základné klasifikačné systémy a morfometrické charakteristiky korytovo-nivných geosystémov. Geomorphologia Slovaca 1: 5-20.

Leopold L.B., Wolman M.G., Miller J.P., 1964, Fluvial processes in geomorphology. W.H. Freeman, San Francisco.

Lukniš M., 1972. Reliéf. In: M. Lukniš (eds.), Slovensko 2, Príroda. Vydavatel'stvo Obzor Bratislava.

Lukniš M., Mazúr E., Kvitkovič J., 1964. Geomorfologické pomery v rajóne VSŽ. In: K. Ivanička (eds.), Geografia regiónu Východoslovenských železiarní. Bratislava Actageol. geogr. Univ. Comen., Geographica 4: 48-57.

Łyp M. 2012. Parametry morfometryczne zlewni i koryt rzecznych $\mathrm{w}$ badaniach systemu fluwialnego. In: $\mathrm{K}$. Krzemień (eds.), Struktura koryt rzek i potoków - studium metodyczne. Instytut Geografi i Gospodarki Przestrzennej UJ, Kraków: 43-53.

Maglay J., Halouzka R., Baňacký V., Pristaš J., Janočko J., 1999. Neotektonická mapa Slovenska 1:500,000. ŠGÚDŠ, MŽP SR, Bratislava.

Maglay J., Moravcová M., Vlačiky M., Šefčík P., 2011. Prehl'adná geologická mapa kvartéru Slovenskej republiky, M: 1:200,000. ŚGÚDŠ, MŽP SR, Bratislava.

Mazúr E., 1963. Žilinská kotlina a prilahlé pohoria (Geomorfológia a kvartér). Bratislava, Vydavatel'stvo Slovenskej akadémie vied. 
Mazúr E., Lukniš M., 1980. Geomorfologické členenie. In: E. Mazúr (eds.), Atlas SSR. Bratislava Veda:54-55.

Montgomery D.R., Buffington J.M., 1998. Channel processes, classification, and response. In: R. Naiman, R. Bilby, River Ecology and Management. New York, Springer-Verlag: 13-42.

MZP [Ministerstvo Životného Prostredia], 2011. Predbežné hodnotenie povodňového rizika v čiastkovom povodi Hornádu. Online: http://www.minzp.sk/files/sekcia-vod/hornad-prilohy.pdf (accessed 4.03.2015).

Pišút P., Tomčíková I., 2008. Rekonštrukcia vývoja rieky Smrečianky $\mathrm{v}$ jej odozvovej zóne podl'a historických máp. Geographia Cassoviensis. 2 (1): 122-127.

Pospíšil L., Husák L'., 1985. Príspevok geofyziky k poznaniu stavby východoslovenských neovulkanitov a ich podložia. Západné Karpaty - Geológia 10. Bratislava GÚDŠ.

Riggs H. C., 1978. Streamflow characteristics from channel size. Am. Soc. Civil Eng., Journal Hydraulics Div. 104(HY1): 87- 96.

Rosgen D. L., 1994. Classification od natural rivers. Catena 22: 169-199.
Roy S., Sahu A.S., 2015. Quaternary tectonic control on channel morphology over sedimentary low land: A case study in the Ajay-Damodar interfluve of Eastern India. Geoscience Frontiers 6(6): 927-946.

Schumm S.A., 1977. The Fluvial System. John Wiley and Sons, New York.

Schumm S.A., Lichty R.W., 1965. Time, Space and Causality in Geomorphology. American Journal of sciences 263: 110-119.

Škarpich V., Hradecký J., 2013. Water management of beskidian gravel-bed streams in the Morávka River basin. Acta Musei Beskidensis 5: 5-12.

Škarpich V., Hradecký J., Dušek R., 2013. Complex transformation of the geomorphic regime of channels in the forefield of the Moravskoslezské Beskydy Mts. Case study of the Morávka River (Czech Republic). Catena, 111: 25-40.

Zámolyi Z., Székely B., Draganits E., Timár G., 2010. Neotectonic control on river sinuosity at the western margin of the Little Hungarian Plain. Geomorphology 122: 231-243. DOI: 10.1016/j.geomorph.2009.06.028.

Zuchiewicz W., 1998. Quaternary tectonics ofthe Outer West Carpathians, Poland. Tectonophysics 297: 121-132. 